\title{
Effect of different $n-6 / n-3$ fatty acid proportion oil sources on reproduction performance and fatty acid profile of milk in modern genotype sows - Preliminary results
}

\author{
Róbert Roszkos ${ }^{1,3}$ - Tamás Tóth ${ }^{2,3}$ - Hedvig Fébel ${ }^{4}-$ Miklós Mézes $^{1}$ \\ ${ }^{1}$ Szent István University, Department of Nutrition, Gödöllő, Hungary \\ ${ }^{2}$ Széchenyi István University, Agricultural and Food Research Centre, Győr, Hungary \\ ${ }^{3}$ ADEXGO Kft., Balatonfüred, Hungary \\ ${ }^{4}$ National Agricultural Research and Innovation Center, Research Institute for Animal Breeding, Nutrition and Meat Science, Herceghalom, \\ Hungary \\ robert.roszkos@adexgo.hu
}

\begin{abstract}
SUMMARY
This study was conducted to investigate the effects of supplemental n-6 and n-3 fatty acids on sow's milk fatty acid composition during the lactation period and on reproductive efficiency of sows in the subsequent gestation period. Data were collected on a total of 213 DanBred sows (108 control and 105 experimental) representing parity of 2-7, respectively. Control and experimental sows were placed in the same housing conditions during lactation and gestation period. Control group received $6.3 \mathrm{~g}$ of sunflower oil (SO) per kg feed as $n-6$ fatty acid supplementation, whilst experimental animals received the same amount of fish oil (FO) as $n$-3 fatty acid source. Diets were corn mealextracted soybean meal based. The experiment was conducted in one replication as being a part of a longer and more comprehensive trial. It was found that the consumed long-chain polyunsaturated fatty acids (LC-PUFAs) appeared in the sow's milk and changed its fatty acid profile. With this alteration, the n-6/n-3 ratio of experimental (FO) sows' milk were narrower than in SO group (SO: 13.82 vs. FO: 5.89). The benefits of $n-3$ fatty acids supplementation were evident for the subsequent reproduction cycle, when experimental sows heated more reliable and earlier than control (weaning to oestrus interval: SO: 5.86 vs. FO: 4.48 days). Only $2.33 \%$ of experimental sows (FO) did not heat within 7 days after weaning, but this was $12.36 \%$ in the control group (SO). The present study requires further research to evaluate the effect of $n-3$ fatty acids on maintenance of pregnancy and improved subsequent litter size.
\end{abstract}

Keywords: $n$-3 fatty acids; reproduction; sow; sow milk

\section{INTRODUCTION}

The long-chain polyunsaturated fatty acids (LCPUFAs) have been in the focus of scientific research for a long time. Linoleic acid (C18:2, n-6) and $\alpha$-linolenic acid (C18:3, n-3) are essential for mammals, so they can be taken only from feeds (Di Pasquale, 2009).

LC-PUFAs influence the reproductive performance in such a way that they positively affect follicle development and act on the formation of prostaglandins and sexual steroids (Wathes et al., 2007). Increasing the number of ovulating follicle enhance the progesterone levels after ovulation, which has a positive effect on the early embryonic development (Geisert and Yelich, 1997).

LC-PUFAs are able to pass through the placenta into the foetus via bloodstream and can also be excreted through sow milk (Greenberg et al., 2008; Sampels et al., 2011). The positive effects of LC-PUFAs on reproduction is clearly linked to $n-3$ fatty acids. The most known n-3 PUFAs are $\alpha$-linolenic acid (C18:3, n3), eicosapentaenoic acid (EPA; C20:5, n-3) and docosahexaenoic acid (DHA; C22:6, n-3).

The most promising effects of n-3 PUFAs described in the technical literature are on the performance parameters of the subsequent parturition, when sows are fed with n-3 PUFAs rich diet during lactation (Smits et al., 2011; Rosero, 2016). Smits et al. (2011) found that $3.3 \mathrm{~g} / \mathrm{kg}$ salmon oil (n-3 PUFAs) supplementation of the diet of F1 (Large White $\times$ Landrace) sows from day 107 of gestation until weaning, did not affect the parameters of current lactation (neither sows' nor piglets'), but the period to next conception was reduced in the experimental group (7.8 vs. 6.3 days). Conception and farrowing rate improved by $(74.8 \% \mathrm{vs}$. $75.8 \%)$ and $(72.1 \%$ vs. $73.5 \%)$, whilst total litter size and live born piglet number increased (9.3 vs. 10.3). In the study of Rosero et al. (2016) with PIC Camborough sows, the increasing amount of $\alpha$-linolenic acid in the diet $(1.5,3.0,4.5 \mathrm{~g} / \mathrm{kg}$ feed; with $4 \%$ of different mixtures of canola, corn and flaxseed oils) increased the farrowing rate, decreased the wean-to-oestrus interval, and the culling rate of sows as compared to the not supplemented controls.

Taugbol et al. (1993) found that $50 \mathrm{~mL}$ daily cod liver oil supplementation of Norwegian Landrace sows significantly increased the EPA and DHA content of milk at parturition and after 2 weeks of lactation. However, no effect was found on weight gain or on the overall morbidity of piglets.

In the study of Fritsche et al. (1993) menhaden fish oil (MFO) was used to substitute lard in the amount of 3.5 , and $7 \%$ of the diet. The MFO treatment significantly increased the content of n-3 PUFAs in the blood serum and milk of crossbred (Landrace $\times$ Duroc) sows, but decreased the levels of arachidonic acid (C20:4, n-6). Piglet blood serum n-3 PUFA levels were also elevated within 24 hours after birth in the experimental groups.

Based on the scientific literature our main purpose was to investigate the effect of n-3 PUFAs supplementation (fish oil, FO) at practically important low dose (under 1\%) during lactation and early gestation period opposite to increased n-6 PUFAs 
(sunflower oil, SO) supplementation on the reproduction performance and the fatty acid composition of sow's milk in a high proliferative modern hybrid, Danbred, which was not investigated previously.

\section{MATERIALS AND METHODS}

\section{Animals and experimental conditions}

The trial was conducted at a Hungarian large-scale "farrow to nursery" swine farm breeding DanBred (DanBred Genetics, Copenhagen). The farm works with 2,500 sows in one week batch-management system. The farrowing rooms contain 48 farrowing pens. The average number of live born piglets per sow was 18.6 , so the farm had to use $10-15 \%$ of the sows as nursery sows for piglets over the count of working tits. As first parity sows are also used for cross-fostering, they were excluded from the trial, hence long suckling period had disadvantageous effect on their body condition and further reproduction performance. The housing and feeding system of the farm are absolutely unified, so control and experimental animals were kept in the same circumstances. From the experimental group data of 105 sows could be evaluated and 108 that of the control. As the trial is still ongoing and a lot of different other parameters are being collected, the data and results of the $1^{\text {st }}$ replication presented in this paper.

The experiment started before the farrowing, approximately at the days of $110-114$ of gestation, when sows were moved into farrowing pens and ended when the sows were ultrasonically scanned for pregnancy at the $30^{\text {th }}$ day after artificial insemination (AI). Sows were fed according to feeding curves (BigDutchman feeders; Big Dutchman International GmbH, Germany) all time in the lactation and the first part of gestation period, and had a free access to drinking water.

\section{Dietary treatments}

Dietary treatments (lactation and gestation compound feeds) as was used in the trial were formulated on corn-barley-soybean meal based. The experimental lactation diet was supplemented with FO on inorganic carrier in inclusion rate of $6.3 \mathrm{~g} / \mathrm{kg}$ feed, whilst control group received SO in the same inclusion rate (Table 1). Supplements were used instead of barley in the diets.

Composition and analysed nutrient content of the control and the experimental diets

\begin{tabular}{|c|c|c|c|c|}
\hline \multirow[b]{2}{*}{ Composition } & \multicolumn{2}{|c|}{ Lactation feeds } & \multicolumn{2}{|c|}{ Gestation feeds } \\
\hline & Control diet & Experimental diet & Control diet & Experimental diet \\
\hline Corn $(\mathrm{kg})$ & 440 & 440 & 225 & 225 \\
\hline Barley (kg) & 267 & 267 & 513 & 513 \\
\hline Soybean meal (kg) & 150 & 150 & 50 & 50 \\
\hline Others $^{1,2}(\mathrm{~kg})$ & 60 & 60 & 170 & 170 \\
\hline Vitamin and mineral premix $(\mathrm{kg})^{3,4}$ & 53 & 53 & 37 & 37 \\
\hline Fat supplement $(\mathrm{kg})$ & 20 & 20 & 5 & 5 \\
\hline Fish oil on inorganic carrier ${ }^{5}(\mathrm{~kg})$ & - & 10 & - & - \\
\hline Sunflower oil on inorganic carrier ${ }^{5}(\mathrm{~kg})$ & 10 & - & - & - \\
\hline Total $(\mathrm{kg})$ & 1,000 & 1,000 & 1,000 & 1,000 \\
\hline \multicolumn{5}{|c|}{ Nutrient/energy content (calculated values) } \\
\hline Dry matter $(\%)$ & 89.25 & 89.26 & 89.87 & 89.87 \\
\hline DEs (MJ/kg) & 13.91 & 13.92 & 12.39 & 12.40 \\
\hline MEs (MJ/kg) & 13.44 & 13.44 & 11.97 & 11.97 \\
\hline Crude protein (\%) & 16.03 & 16.03 & 12.75 & 12.75 \\
\hline Ether extract (\%) & 6.41 & 6.42 & 4.26 & 4.27 \\
\hline Crude fibre $(\%)$ & 3.65 & 3.65 & 6.19 & 6.19 \\
\hline $\operatorname{Ash}(\%)$ & 5.46 & 5.45 & 4.87 & 4.86 \\
\hline Total Lys (g/kg) & 1.04 & 1.04 & 0.69 & 0.69 \\
\hline Total Met $(\mathrm{g} / \mathrm{kg})$ & 0.34 & 0.34 & 0.28 & 0.28 \\
\hline Total Met + Cys $(\mathrm{g} / \mathrm{kg})$ & 0.62 & 0.62 & 0.52 & 0.52 \\
\hline Total Thr $(\mathrm{g} / \mathrm{kg})$ & 0.68 & 0.68 & 0.51 & 0.51 \\
\hline
\end{tabular}

${ }^{1}$ Lactation feed contained per ton: $30 \mathrm{~kg}$ of Alphasoy pig 530, $10 \mathrm{~kg}$ of fish meal, $20 \mathrm{~kg}$ of dried apple

${ }^{2}$ Gestation feed contained per ton: $120 \mathrm{~kg}$ of pressed sugar beet pulp, $50 \mathrm{~kg}$ of sunflower meal

${ }^{3}$ Supplied per kg of lactation feed: vitamin A, $15900 \mathrm{IU}$; vitamin D, $1590 \mathrm{IU}$; vitamin E, $90 \mathrm{mg}$; vitamin K, $2.1 \mathrm{mg}$; thiamine, $1.6 \mathrm{mg}$; riboflavin, $5.3 \mathrm{mg}$; niacin, $26.5 \mathrm{mg}$; pantothenic acid, $18.6 \mathrm{mg}$; pyridoxine, $3.7 \mathrm{mg}$; folic acid, $0.8 \mathrm{mg}$; vitamin B12, $0.03 \mathrm{mg}$; $1.6 \mathrm{mg}$; Se, $0.42 \mathrm{mg}$; choline, $477 \mathrm{mg}$ from choline chloride; Zn, $127.2 \mathrm{mg}$, Fe $95.4 \mathrm{mg}$, Mn $53 \mathrm{mg}$, and Cu $21.2 \mathrm{mg}$

${ }^{4}$ Supplied per kg of gestation feed: vitamin A, $11100 \mathrm{IU}$; vitamin D, $1110 \mathrm{IU}$; vitamin E, $59.2 \mathrm{mg}$; vitamin $\mathrm{K}$, $1.5 \mathrm{mg}$; thiamine, $1.1 \mathrm{mg}$; riboflavin, $3.7 \mathrm{mg}$; niacin, $18.5 \mathrm{mg}$; pantothenic acid, $13 \mathrm{mg}$; pyridoxine, $2.6 \mathrm{mg}$; folic acid, $0.6 \mathrm{mg}$; vitamin B12, $0.02 \mathrm{mg}$; I, $1.1 \mathrm{mg}$; Se, 0.3 mg; choline, $333 \mathrm{mg}$ from choline chloride; Zn, $88.8 \mathrm{mg}$, Fe $66.6 \mathrm{mg}$, Mn $37 \mathrm{mg}$, and Cu $14.8 \mathrm{~m}$

${ }^{5}$ Each feed supplements contained $6.3 \mathrm{~kg}$ of fish oil (FO) or sunflower oil (SO) and $3.7 \mathrm{~kg}$ silicium dioxide (Producer: ADEXGO Kft., Hungary) 
As the trial lasted till the $30^{\text {th }}$ day of gestation, fish and sunflower oil did not mixed to the gestation diet, but those were added by "on top" feeding in this period. The average amount of gestation feed during this phase was $3.6 \mathrm{~kg}$, hence $22.5 \mathrm{~g}$ of each complementary feed (NO, FO) was administered daily, which was the same inclusion rate as in the lactation phase.
Table 2 shows the analytical and fatty acid composition of used complementary feeds. The original oil sources ( $\mathrm{SO}, \mathrm{FO})$ were taken onto inorganic carrier (silicium dioxide) in a proportion of 63 to $37 \%$. As fish oil and sunflower oil have almost the same energy content, and they were used in the same inclusion rate, the diets can be considered as isocaloric ones.

Chemical composition and fatty acid content of SO and FO (on inorganic carrier) used in the experiment

\begin{tabular}{|c|c|c|}
\hline Analysed chemical composition & $\begin{array}{c}\text { SO } \\
\text { on inorganic carrier }^{1}\end{array}$ & $\begin{array}{c}\text { FO } \\
\text { on inorganic carrier }{ }^{2}\end{array}$ \\
\hline Dry matter $\%$ & 98.75 & 98.75 \\
\hline Ether extract \% & 61.45 & 61.93 \\
\hline Crude protein $\%$ & 0.25 & 0.20 \\
\hline Ash \% & 34.30 & 34.00 \\
\hline $\operatorname{MEs}(\mathrm{MJ} / \mathrm{kg})^{3}$ & 20.8 & 20.9 \\
\hline DEs $(\mathrm{MJ} / \mathrm{kg})^{3}$ & 21.0 & 21.1 \\
\hline Analysed fatty acid content & \multicolumn{2}{|c|}{ mg fatty acid/g feed supplement } \\
\hline $\mathrm{C} 14: 0$ & 0.95 & 35.01 \\
\hline C16:0 & 39.20 & 76.89 \\
\hline $\mathrm{C} 16: 1$ & 0.80 & 21.71 \\
\hline C18:0 & 18.51 & 13.63 \\
\hline $\mathrm{C} 18: 1(\mathrm{n}-9 \mathrm{c})$ & 205.52 & 77.50 \\
\hline $\mathrm{C} 18: 2(\mathrm{n}-6 \mathrm{c})$ & 303.02 & 23.75 \\
\hline $\mathrm{C} 18: 3(\mathrm{n}-3)$ & 0.21 & 8.80 \\
\hline C20:1 (n-9) & 0.99 & 34.32 \\
\hline C20:2 (n-6) & - & 1.61 \\
\hline C20:3 (n-6) & - & 0.61 \\
\hline $\mathrm{C} 22: 0$ & 3.72 & 0.33 \\
\hline$C 20: 5(n-3)$ & & 47.28 \\
\hline $\mathrm{C} 24: 0$ & 0.84 & 0.08 \\
\hline $\mathrm{C} 22: 5(\mathrm{n}-3)$ & - & 14.26 \\
\hline $\mathrm{C} 22: 6(\mathrm{n}-3)$ & - & 57.89 \\
\hline Total fatty acid (mg/g feed) & 575.73 & 423.66 \\
\hline$n-6 / n-3$ & $1,433.81$ & 0.22 \\
\hline
\end{tabular}

${ }^{1} \mathrm{SO}($ control $)=$ sunflower oil on inorganic carrier $(10 \mathrm{~g} / \mathrm{kg}) ;{ }^{2} \mathrm{FO}($ experimental $)=$ fish oil on inorganic carrier $(10 \mathrm{~g} / \mathrm{kg})$ ${ }^{3}$ calculated values

Fatty acid content of lactation and gestation diets were also examined (Table 3). As complementary SO and $\mathrm{FO}$ were mixed into lactation diets, the ratio of $\mathrm{n}$ 6/n-3 fatty acids show a great difference (16.76 vs. 6.73) between control and experimental diets. No complementary feed was mixed into gestation feed (see above).

\section{Chemical and other analysis}

Feed samples of all type of feeds were analysed for dry matter, crude protein, ether extract, crude fibre, ash, calcium and phosphorus content according to the AOAC (2006) methods. Fish oil and sunflower oil on inorganic carriers were also analysed for the same parameters (Table 2).

Feed samples (lactation and gestation compound feeds) were collected right from the feeders of the animals. Every sample for investigation contained 8-
10 portions, each took out from individual feeders and then mixed together.

Fatty acid composition of feed and milk samples were defined by the following method. One gram of feed or one $\mathrm{mL}$ of milk sample was hydrolysed with the addition of $40 \mathrm{ml}$ methanol and $6 \mathrm{ml}$ of $\mathrm{NaOH} 50 \%$ solution and $1.6 \mathrm{ml}$ of inner standard $(500 \mathrm{mg}$ nonadecaenoic acid/100 mL toluene and isopropanol 2:1) under $80^{\circ} \mathrm{C}$ for $60 \mathrm{~min}$. After chilling, lipid was extracted with chloroform and then the tube was evaporated. Fatty acid methyl esters were prepared with $14 \%$ boron trifluoride/methanol solution. $4 \mathrm{ml}$ of hexane was added and then the tube was vortexed, and approximately $1 \mathrm{~mL}$ of the upper phase containing the methyl esters was stocked in amber-coloured glass bottle and keep at $-18^{\circ} \mathrm{C}$ for later analyses. Analyses of fatty acid methyl esters (FAME) was conducted in a gas chromatograph (GCMS-QP2010 SE - Gas Chromatography Mass Spectrometer - Shimadzu, S.A., 
Kyoto, Japan) and the components of the methyl esters were separated in a BPX70 capillary column (30 m x $0.25 \mathrm{~mm} \times 0.25 \mu \mathrm{m}$, Phenomenex, USA). GCMS analysis was performed as follows: injection temperature: $220^{\circ} \mathrm{C}$, injection mode: split, flow control mode: linear velocity, pressure: $60.1 \mathrm{KPa}$, total flow: $45.4 \mathrm{ml} / \mathrm{min}$, column flow: $1.03 \mathrm{ml} / \mathrm{min}$, linear velocity: $37.1 \mathrm{~cm} / \mathrm{s}$, purge flow: $3 \mathrm{ml} / \mathrm{min}$, split ratio: 40 .

Analysed fatty acid content of the control and the experimental compound feeds

\begin{tabular}{|c|c|c|c|}
\hline & \multicolumn{2}{|c|}{ Compound feeds (lactation phase) } & \multirow{3}{*}{$\begin{array}{c}\begin{array}{c}\text { Compound feed } \\
\text { (gestation phase) }\end{array} \\
\text { Control/Experimental }^{1}\end{array}$} \\
\hline & Control (SO) & Experimental (FO) & \\
\hline & & $\mathrm{mg}$ fatty acid/g feed & \\
\hline $\mathrm{C} 14: 0$ & 0.38 & 0.77 & 0.11 \\
\hline C16:0 & 9.18 & 9.73 & 4.87 \\
\hline C16:1 & 0.50 & 0.78 & 0.13 \\
\hline C18:0 & 3.37 & 3.49 & 1.27 \\
\hline $\mathrm{C} 18: 1(\mathrm{n}-9 \mathrm{c})$ & 13.17 & 11.91 & 4.49 \\
\hline $\mathrm{C} 18: 2(\mathrm{n}-6 \mathrm{c})$ & 17.22 & 14.17 & 9.94 \\
\hline C18:3 (n-3) & 0.86 & 0.91 & 0.55 \\
\hline C20:1 (n-9) & 0.18 & 0.52 & 0.07 \\
\hline C20:2 (n-6) & 0.03 & 0.06 & 0.02 \\
\hline $\mathrm{C} 20: 3(\mathrm{n}-6)$ & 0.01 & 0.02 & 0.01 \\
\hline $\mathrm{C} 22: 0$ & 0.09 & 0.05 & 0.06 \\
\hline C20:5 (n-3) & 0.06 & 0.48 & - \\
\hline $\mathrm{C} 24: 0$ & 0.06 & 0.04 & 0.06 \\
\hline $\mathrm{C} 22: 5(\mathrm{n}-3)$ & 0.04 & 0.13 & - \\
\hline$C 22: 6 n-3$ & 0.09 & 0.60 & - \\
\hline Total fatty acid (mg/g feed) & 45.61 & 44.09 & 21.80 \\
\hline$n-6 / n-3$ & 16.46 & 6.73 & 18.19 \\
\hline
\end{tabular}

${ }^{1}$ Normal gestation feed without $\mathrm{SO}$ or FO supplementation

\section{Data collection}

In the experiment only multiparous sows (parity 2 7) were involved. Average parity in the control group was $3.46 \pm 1.29$, whilst that of the experimental was $3.54 \pm 1.24$. The number of live born, dead born and mummified piglets, the weaning weight of litters per rooms and the mortality were also recorded.

On the $14^{\text {th }}$ days of lactation, from 5 sow of the experimental and 6 of control group milk samples were collected. First the piglets were separated from the dam after suckling. About 1 hour later, the sows were injected intramuscularly with 10 IU oxytocin and handmilked (Noblet and Etienne, 1989). Samples, stored at $-20^{\circ} \mathrm{C}$, subsequently were analysed for fatty acid composition.

After weaning sows were continuously inspected regarding the beginning of oestrus. The first day when sows can be inseminated was recorded into farm management program (CloudFarms, Cloudfarms s.r.o., Bratislava, Slovakia) and on sow cards, so days from weaning till oestrus could be calculated. Sows inseminated more than 7 days after weaning were counted to have "late" oestrus. 30 days after AI ultrasonic examination was occurred to determine pregnancy rate. Number of culled, dead sows and nursery ones were also recorded respectively.

\section{Statistical analysis}

Data were analysed using the Kolmogorov-Smirnov test, Levene-test and independent-samples t-test or Mann-Whitney U-test (SPSS, IBM, Armonk, NY). In all procedures, the significance level was $\mathrm{p} \leq 0.05$.

\section{RESULTS AND DISCUSSION}

\section{Fatty acid content of sow's milk}

The use of SO and FO changed the fatty acid composition of feeds, which also could be seen in the fatty acid profile of sows' milk (Table 4). The n-6/n-3 ratio of control lactation feed was 16.46 , which led to 13.82 in the sow milk of control group. In case of experimental lactation feed this ratio was 6.73 , which caused a ratio of 5.89 in the milk of sows. Lauridsen and Danielsen (2004) and Jin et al. (2017) investigated the effect of different oil sources (e.g. sunflower oil, soybean oil, rapeseed oil, fish oil, coconut oil and animal fat) on the fatty acid composition of milk of 175 Danish Landrace $\times$ Yorkshire and 80 Large White $\times$ Landrace sows, respectively, and observed that fatty acid levels of milk closely correlated with the fatty acid composition of the dietary fat sources. Yao et al. (2012) found a decrease of n-3 PUFA and $\alpha$-linolenic acid in the diets of Landrace sows, when the $n-6 / n-3$ PUFA ratio was increased. 
Investigating the different fatty acid groups of the sow milk, we did not found statistical differences in the amount of saturated fatty acids (SFAs), monounsaturated fatty acids (MUFAs) or polyunsaturated fatty acids (PUFAs) between control and experimental animals. In an experiment conducted by Fritsche et al. (1993) found significant difference in the amount of milk PUFA, when substituted 7\% menhaden fish oil to lard.

In the group of PUFAs, linoleic acid (LA, C18:2, n6) was significantly lower, whilst conjugated linoleic acid (CLA, c9, t11), eicosapentaenoic acid (EPA,
C20:5, n-3), docosapentaenoic acid (DPA, C22:5, n-3) and docosahexaenoic acid (DHA, C22:6, n-3) were significantly higher in the milk of FO group. These results are very similar to that of Lauridsen and Danielsen (2004) who used the same oil sources, but in $8 \%$ inclusion rate and Jin et al. (2017) who fed $4.1 \%$ palm oil, $3.9 \%$ FO and $3.8 \%$ soybean oil. In the experiment of Taugbol et al. (1993) only EPA and DHA showed significant increase to control on the $14^{\text {th }}$ day of lactation, when $50 \mathrm{ml}$ Cod liver oil was fed against a negative control.

Fatty acid content of the control and the experimental sow's milk

\begin{tabular}{|c|c|c|c|}
\hline Fatty acid (FA) & $\begin{array}{c}\text { Control, SO } \\
\qquad(\mathrm{n}=6) \\
\mathrm{mg} \text { fatty acid } / \mathrm{ml} \text { of milk }\end{array}$ & $\begin{array}{l}\text { Experimental, FO } \\
\quad(\mathrm{n}=5)\end{array}$ & $\mathrm{P}$-value \\
\hline C6:0 & $0.01 \pm 0.00$ & $0.01 \pm 0.00$ & 0.56 \\
\hline C8:0 & $0.03 \pm 0.01$ & $0.03 \pm 0.01$ & 0.73 \\
\hline $\mathrm{C} 10: 0$ & $0.20 \pm 0.04$ & $0.16 \pm 0.04$ & 0.26 \\
\hline C12:0 & $0.27 \pm 0.06$ & $0.22 \pm 0.06$ & 0.26 \\
\hline C14:0 & $3.25 \pm 0.61$ & $2.88 \pm 0.67$ & 0.37 \\
\hline $\mathrm{C} 15: 0$ & $0.08 \pm 0.02$ & $0.07 \pm 0.01$ & 0.36 \\
\hline C16:0 & $27.56 \pm 4.64$ & $23.93 \pm 4.21$ & 0.21 \\
\hline $\mathrm{C} 17: 0$ & $0.14 \pm 0.04$ & $0.13 \pm 0.02$ & 0.80 \\
\hline C18:0 & $3.72 \pm 0.86$ & $3.66 \pm 0.39$ & 0.89 \\
\hline C20:0 & $0.08 \pm 0.01$ & $0.08 \pm 0.01$ & 1.00 \\
\hline $\mathrm{C} 22: 0$ & $0.03 \pm 0.01$ & $0.02 \pm 0.00$ & 0.45 \\
\hline $\mathrm{C} 24: 0$ & $0.02 \pm 0.01$ & $0.02 \pm 0.01$ & 0.54 \\
\hline$\Sigma$ SFAs & $35.4 \pm 6.07$ & $31.2 \pm 5.38$ & 0.26 \\
\hline C14:1 & $0.16 \pm 0.04$ & $0.14 \pm 0.06$ & 0.51 \\
\hline C16:1 & $6.57 \pm 1.52$ & $5.18 \pm 1.60$ & 0.17 \\
\hline $\mathrm{C} 17: 1$ & $0.16 \pm 0.02$ & $0.13 \pm 0.03$ & 0.06 \\
\hline $\mathrm{C} 18: 1(\mathrm{n}-9 \mathrm{t})$ & $0.02 \pm 0.01$ & $0.01 \pm 0.00$ & 0.09 \\
\hline C18:1 (n-7) & $0.01 \pm 0.01$ & $5.77 \pm 7.89$ & 0.79 \\
\hline C18:1 (n-9c) & $22.76 \pm 6.65$ & $17.70 \pm 4.96$ & 0.19 \\
\hline $\mathrm{C} 20: 1$ & $0.25 \pm 0.11$ & $0.29 \pm 0.11$ & 0.56 \\
\hline$\Sigma$ MUFAs & $29.9 \pm 7.76$ & $29.2 \pm 7.59$ & 0.88 \\
\hline C18:2 (n-6t) & $0.01 \pm 0.00$ & $0.01 \pm 0.00$ & 0.74 \\
\hline $\mathrm{C} 18: 2(\mathrm{n}-6 \mathrm{c})$ & $8.99^{\mathrm{a}} \pm 1.18$ & $6.41^{\mathrm{b}} \pm 1.18$ & 0.01 \\
\hline CLA $(\mathrm{c} 9, \mathrm{t} 11)$ & $0.08^{\mathrm{b}} \pm 0.02$ & $0.12^{\mathrm{a}} \pm 0.03$ & 0.05 \\
\hline CLA (t10, c12) & $0.01 \pm 0.01$ & $0.01 \pm 0.00$ & 0.64 \\
\hline C18:3 (n-6) & $0.06 \pm 0.03$ & $0.06 \pm 0.02$ & 0.80 \\
\hline C18:3 (n-3) & $0.38 \pm 0.06$ & $0.38 \pm 0.07$ & 0.96 \\
\hline C20:2 (n-6) & $0.17 \pm 0.05$ & $0.17 \pm 0.06$ & 0.97 \\
\hline $\mathrm{C} 20: 3(\mathrm{n}-6)$ & $0.09 \pm 0.02$ & $0.09 \pm 0.02$ & 0.97 \\
\hline $\mathrm{C} 20: 3(\mathrm{n}-3)$ & $0.02 \pm 0.01$ & $0.03 \pm 0.01$ & 0.23 \\
\hline C20:4 (n-6) & $0.41 \pm 0.09$ & $0.43 \pm 0.05$ & 0.71 \\
\hline $\mathrm{C} 20: 5(\mathrm{n}-3)$ & $0.04^{\mathrm{b}} \pm 0.01$ & $0.18^{\mathrm{a}} \pm 0.04$ & 0.001 \\
\hline $\mathrm{C} 22: 5(\mathrm{n}-3)$ & $0.16^{\mathrm{b}} \pm 0.04$ & $0.29^{\mathrm{a}} \pm 0.07$ & 0.001 \\
\hline $\mathrm{C} 22: 6(\mathrm{n}-3)$ & $0.10^{\mathrm{b}} \pm 0.02$ & $0.36^{\mathrm{a}} \pm 0.07$ & 0.001 \\
\hline$\Sigma$ PUFAs & $10.53 \pm 1.47$ & $8.54 \pm 1.69$ & 0.07 \\
\hline Total fatty acid (mg/ml of milk) & 75.83 & 68.98 & - \\
\hline$\Sigma \mathrm{n} 6$ & 9.81 & 7.30 & - \\
\hline$\sum \mathrm{n} 3$ & 0.71 & 1.24 & - \\
\hline n6/n3 & 13.82 & 5.89 & - \\
\hline
\end{tabular}

SO (control)=sunflower oil on inorganic carrier $(10 \mathrm{~g} / \mathrm{kg}) ; \mathrm{FO}$ (experimental)=fish oil on inorganic

SFAs=saturated fatty acids, MUFAs=monounsaturated fatty acids, PUFAs=polyunsaturated fatty acids

carrier $(10 \mathrm{~g} / \mathrm{kg})$

a,b: different superscripts in the same row means significant difference at $p<0.05$ level 
Different fatty acids of the sow milk by their length of carbon chain were also evaluated (Table 5). There was no fatty acids with five or fewer carbon atoms, namely short-chain fatty acids (SCFAs) in the analysed milk samples. The amount of medium-chain fatty acids (MCFAs, 6 to 12 carbon atoms) were very low without considerable difference in the treatments. Long-chain fatty acids (LCFAs) having 13 to 21 carbon atoms were in the greatest amount (98-99\% of all type) in the milk of sows being a larger amount in the control milk samples. Very long chain fatty acids (VLCFAs 22 or more carbon atoms) were also present in very moderate amount, but almost 3 times more in the milk of experimental animals, which was caused by the significant increase of DPA $(\mathrm{C} 22: 5, \mathrm{n} 3)$ and DHA $(\mathrm{C} 22: 6, \mathrm{n}-6)$ in the milk, as was also found by Taugbol et al. (1993).

Table 5

The amount of fatty acids according to their carbon chain length in the control and the experimental sow's milk (calculated values from Table 4)

\begin{tabular}{lcc}
\hline Fatty acid (FA) & $\begin{array}{c}\text { Control, SO } \\
\text { mg fatty acid } / \mathrm{ml} \text { of milk }\end{array}$ & $\begin{array}{c}\text { Experimental, FO } \\
\text { SCFAs }\end{array}$ \\
MCFAs & - & - \\
LCFAs & 0.50 & 0.43 \\
VLCFAs & 75.06 & 67.91 \\
\hline
\end{tabular}

SO (control): sunflower oil on inorganic carrier $(10 \mathrm{~g} / \mathrm{kg}) ; \mathrm{FO}$ (experimental): fish oil on inorganic carrier $(10 \mathrm{~g} / \mathrm{kg})$

SCFAs $=$ short-chain fatty acids $(<\mathrm{C} 5)$; MCFAs $=$ medium-chain fatty acids (C6-C12);

LCFAs $=$ Long-chain fatty acids $(\mathrm{C} 13-21)$; VCFAs $=$ Very long chain fatty acids $(>\mathrm{C} 22)$
The results showed, that FO supplementation had an obvious effect on fatty acid profile of sow milk, enhancing the n-3 fatty acid content of the body, thus n-3 fatty acids are capable to act in other physiological processes, such as reproduction.

\section{Reproduction performance of sows}

Table 6 contains the data of the sow's reproductive performance during the experiment. There was no significant difference between treatments in the number of culled (14.8vs. $14.3 \%$ and died sows (2.8vs. 1.9\%), furthermore in the number of inseminated (82.4 vs. $83.8 \%$ ) and pregnant sows (100 vs. $97.7 \%$ ). These two latter data were extremely good in both groups during the trial. The main difference of the treatments revealed in the number of later heating sows (more than 7 days wean to oestrus interval) and in the average days till oestrus. This latter was almost 1.5 days shorter in the experimental group (4.48 vs. 5.86 days) but this different did not prove statistically. The proportion of animals had a later oestrus was more advantageous in the experimental group ( $2.3 \%$ vs. $12.4 \%)$.

In the trial of Mateo et al. (2014) with Camborough gilts, there was no difference in the days till oestrus between negative control and experimental animals (4.8 vs. 4.6 days). In this trial experimental animals received $0.2 \%$ of $n-3$ fatty acid containing oil source in encapsulated, protected form (Gromega, JBS United, Sheridan, IN). Similarly to our results Smits et al. (2011) did not find significant difference neither in wean to oestrus interval (7.8 vs. 6.4 days) or in conception rate $(74.8$ vs. $75.8 \%)$ between negative control and $3.3 \mathrm{~g} / \mathrm{kg}$ of fish oil supplementation. Likewise Rosero et al. (2016) neither experienced significant difference in case of $0.45 \% \alpha$-linolenic acid administration during lactation in the percentage of wean to bred or pregnant to wean animals, but found significant difference in wean to oestrus interval (4.6 vs. 3.7 days).

Reproduction parameters of the sows during the experiment

\begin{tabular}{lccc}
\hline & Control, SO & Experimental, FO & P-value \\
\hline Number of sows & 108 & 105 & - \\
Number of nursing sows & 9 & 16 & - \\
Number of culled sows & $16(14.81 \%)$ & $15(14.29 \%)$ & - \\
Number of died sows & $3(2.78 \%)$ & $2(1.90 \%)$ & - \\
Number of inseminated sows & $89(82.41 \%)$ & $88(83.81 \%)$ & - \\
Number of pregnant sows & $89(100.00 \%)$ & $86(97.7 \%)$ & - \\
Number of later heating sows ${ }^{1}$ & $11(12.36 \%)$ & $2(2.33 \%)$ & - \\
Days till oestrus & $5.86 \pm 5.43$ & $4.48 \pm 3.16$ & - \\
Number of weaned piglets per litter & 13.14 & 12.95 & - \\
Av. weight of weaned litters & 84.74 & 83.39 & - \\
Av. weight of weaned piglets & 6.45 & 6.44 & - \\
\hline
\end{tabular}

SO (control): sunflower oil on inorganic carrier (10 kg/t); FO (experimental): fish oil on inorganic carrier (10 kg/t)

${ }^{1}$ More than 7 days till oestrus 
Our results suggested that n-3 fatty acid supplementation of the lactation diet may have a positive effect on follicle maturation, thus ovulation occurs earlier so fewer sows pause their oestrus cycle and need to be inseminated in a later period or in the next cycle. From economical point of view it means, that experimental animals produced more beneficial, because have less open days during their production.

\section{Piglet performance}

Being a large swine farm, mortality, weaned number and weight of piglets were recorded cumulated by farrowing rooms. Because of this attribution, piglet performance could not be evaluated statistically. The previous studies reporting the effects of n-3 PUFAs on pre-weaning growth and mortality of piglets are controversial. For instance Smits et al. (2011) found that $0.33 \%$ supplementation of salmon oil did not affect the birth weight, pre-weaning average daily weight gain (ADWG) or mortality of suckling piglets. In contrary, Cools et al. (2011) reported a decreased piglet weaning weight, and higher pre-weaning mortality in case of $0.5 \%$ fish oil supplementation of the Rattlerow Seghers sows' diet. Rooke et al. (2001) found that different amount (0-2\%) maternal supplementation with salmon oil during lactation reduced the pre-weaning mortality and Luo et al. (2013) reported improved daily weight gain of piglets from Large White $\times$ Landrace sows fed with $7 \%$ fish oil. Nevertheless, weight gain of piglets and pre-weaning mortality can be influenced by many other factors, so we rather focused on reproduction parameters of sows in this experiment.

\section{Later data and results}

The data and results presented here are only a part of greater field experiment, which inspects a longer period of sows' reproduction performance. Our further purposes are to evaluate the effect of n-3 fatty acids on subsequent litter size, antioxidant status and also the hormonal profile of high proliferated, modern sows. In order to this, there will be conducted a second replication of the experiment and blood samples will be also examined.

\section{CONCLUSION}

Based on these preliminary results the following conclusions can be drawn. Fish oil supplementation of lactation and early gestation diet in $0.63 \%$ (on $0.37 \%$ of inorganic carrier), opposite to the same amount of sunflower oil has improved the reproduction parameters of multiparous DanBred sows just after weaning. Fish oil supplementation improved the number of ordinary heating sows and reduced the weaning to oestrus interval with 1.4 days, which was not statistically significant $(\mathrm{p}>0.05)$, but measurable from practical point of view, due to high cost of open days. This latter result, similar to other experiences from literature, was not statistically significant, but can have practical importance. It could lead to more beneficial production in a large scale swine farm, due to less open days of sows. In addition n-3 PUFAs feeding of sows have an effect on fatty acid profile of sow milk. The reduction of $n-6 / n-3$ ratio in milk shows that $n-3$ fatty acids can be utilized in the body of sows used for physiological advantageous purposes and via sow milk they could also be ingested by piglets achieving the same advantages.

As these preliminary results are only came from one replication of the trial, we will continue the investigations, and conduct more replications and evaluate additional parameters, which could reinforce our hypothesis regarding advantageous effect of fish oil on reproduction of hyperprolific, modern sows.

\section{ACKNOWLEDGEMENTS}

Special thanks to Csaba Palkó, who conducted the analytical evaluations and also helped a lot in transport of samples during the whole experiment.

\section{REFERENCES}

Association of Official Analytical Chemists (2006): Official methods of analysis. $18^{\text {th }}$ ed. AOAC, Washington, DC.

Cools, A.-Maes, D.-Papadopoulos, G.-Vandermeiren, J. A.-Meyer, E.-Demeyere, K.-De Smet, S.-Janssens, G. P. J. (2011): Doseresponse effect of fish oil substitution in parturition feed on erythrocyte membrane characteristics and sow performance. J Anim Physiol Anim Nutr. 95. 125-136. https://doi.org/10.1111/j.1439-0396.2010.01119.x

Di Pasquale, M. G. (2009): The essentials of essential fatty acids. J Diet Suppl. 6. 143-161. https://doi.org/10.1080/19390210902861841

Fritsche, K. L.-Huang, S. C.-Cassity, N. A. (1993): Enrichment of omega-3 fatty acids in suckling pigs by maternal dietary fish oil supplementation. J Anim Sci. 71. 1841-1847. https://doi.org/10.2527/1993.7171841x

Geisert, R. D.-Yelich, J. V. (1997): Regulation of conceptus development and attachment in pigs. J Reprod Fertil Suppl. 52. $133-149$.
Greenberg, J. A.-Bell, S. J.-Van Ausdal, W. (2008): Omega-3 fatty acid supplementation during pregnancy. Rev Obstet Gynecol. 1. $162-169$.

Jin, C.-Fang, Z.-Lin, Y.-Che, L.-Wu, C.-Xu, S.-Feng, B.-Li, J.$\mathrm{Wu}$, D. (2017): Influence of dietary fat source on sow and litter performance, colostrum and milk fatty acid profile in late gestation and lactation. Anim. Sci. J. 88. 1768-1778. https://doi.org/10.1111/asj.12836

Lauridsen, C.-Danielsen, V. (2004): Lactational dietary fat levels and sources influence milk composition and performance of sows and their progeny. Livest. Prod. Sci. 91. 95-105. https://doi.org/10.1016/j.livprodsci.2004.07.014

Luo, J.-Huang, F.-Xiao, C.-Fang, Z.-Peng, J.-Jiang, S. (2013): Responses of growth performance and proinflammatory cytokines expression to fish oil supplementation in lactation sows' and/or weaned piglets' diets. Biomed Res Int. 905918. http://dx.doi.org/10.1155/2013/905918 
Mateo, R. D.-Carroll, J. A.-Hyun, Y.-Smith, S.-Kim S. W. (2014) Effect of dietary supplementation of $n-3$ fatty acids and elevated concentrations of dietary protein on the performance of sows. $\mathbf{J}$ Anim. Sci 87. 948-959. https://doi.org/10.2527/jas.2008-0964

Noblet, J.-Etienne, M. (1989): Estimation of Sow Milk Nutrient Output. J Anim Sci. 67. 3352-3359.

Price, P. T.-Nelson, C. M.-Clarke, S. D. (2000): Omega-3 polyunsaturated fatty acid regulation of gene expression. Curr Opin Lipidol. 11. 3-7.

Rooke, J. A.-Sinclair, A. G.-Ewen, M. (2001): Changes in piglet tissue composition at birth in response to increasing maternal intake of long-chain n-3 polyunsaturated fatty acids are non-linear. $\mathrm{Br} \quad \mathrm{J}$ Nutr. 86. 461-470. https://doi.org/10.1079/BJN2001422

Rosero, D.-Boyd, D.-McCulley, M.-Odle, J.-Heugten, E. (2016) Essential fatty acid supplementation during lactation is required to maximize the subsequent reproductive performance of the modern sow. Anim Reprod Sci. 168. 151-163. https://doi.org/10.1016/j.anireprosci.2016.03.010

Sampels, S.-Pickova, J.-Hörgber, A.-Neil, M. (2011): Fatty acid transfer from sow to piglet differs for different polyunsaturated fatty acids (PUFA). Physiol Res. 60. 113-124.
Smits, R. J.-Luxford, B. G.-Mitchell, M.-Nottle, M. B. (2011): Sow litter size is increased in the subsequent parity when lactating sows are fed diets containing n-3 fatty acids from fish oil. J Anim Sci. 89. 2731-2738. https://doi.org/10.2527/jas.2010-3593

Taugbol, O.-Framstad, T.-Saarem, K. (1993): Supplements of Cod Liver Oil to Lactating Sows. Influence on Milk Fatty Acid Composition and Growth Performance of Piglets. J Vet Med. 40. 437-443. https://doi.org/10.1111/j.1439-0442.1993.tb00650.x

Wathes, D. C.-Abayasekara, D. R. E.-Aitken, R. J. (2007): Polyunsaturated fatty acids in male and female reproduction. Biol Reprod. $77 . \quad 190-201$. https://doi.org/10.1095/biolreprod.107.060558

Yao, W.-Li, J.-Wang, J.-Zhou, W.-Wang, O.-Zhu, R.-Wang F.Thacker, P. (2012): Effects of dietary ratio of n-6 to n-3 polyunsaturated fatty acids on immunoglobulins, cytokines, fatty acid composition, and performance of lactating sows and suckling piglets. J. Anim. Sci. Biotechnol. 3. 43. https://doi.org/10.1186/2049-1891-3-43 